\section{The Sir Ralph Forster Tablet at University College, London.}

VISCOUNT CHELMSFORD, chairman of the University College Committee, unveiled, in the presence of a distinguished audience representative of chemical teaching and of chemical industry, a marble tablet placed in the hall of the Chemistry Laboratories at University College to commemorate the munificent donations made by Sir Ralph Forster, Bt., towards the erection and equipment of these laboratories.

Lord Chelmsford, in his opening speech, referred to the old Chemistry Laboratories erected in I87I by the late Prof. Alexander Williamson, which, though in their time the latest thing in chemical laboratories, had proved quite insufficient and inadequate botn in space and in equipment. They had, nevertheless, proved the scene of some of the greatest discoveries made by the late Sir William Ramsay, ably supported by Prof. Collie, Prof. Baly, and Prof. Travers. $\mathrm{He}$ recalled how Sir Ralph Forster had intervened at the last moment with a contribution of $4500 l$. just two days before the option for the purchase of the present site of the Chemistry Laboratories was to expire on January 3I, I9II. At a later date, when the question of the funds for the erection and equipment of the buildings arose, Sir Ralph Forster had again come forward, this time with a donation of 30,000 . Lord Chelmsford dwelt upon the need for private benefactors to carry on the work thus begun, and mentioned that a sum of $\mathrm{I}_{5}, \mathrm{oool}$. is still needed to complete the physical chemical equipment and the electrical installation in the new laboratories.

The Vice-Chancellor of the University of London, Mr. H. J. Waring, speaking in the name of the Senate of the University, expressed to Sir Ralph Forster the grateful thanks of the University for his striking and timely munificence. The Vice-Chancellor developed further the theme already mentioned by Lord Chelms ford, namely, the urgent need for private benefactors for university education in this country, to supplement the funds devoted to university education by the Treasury through the University Grants Committee.

Prof. J. Norman Collie gave an interesting account of the conditions which prevailed in the old Chemistry Laboratories when Sir William Ramsay and he began their work there in 1887 , and referred to the work which had been carried out in those laboratories during the time when Sir William Ramsay and himself had worked in them from I887 until I9I2.

Sir Ralph Forster replied, expressing his deep appreciation of the recognition given to his help by the perpetuation of his name in connexion with University College. He expressed his sense of the importance of the work which is being carried on at University College, not only in chemistry but also in other branches of study. Sir Ralph Forster explained that from his earliest days he had been deeply impressed by the need for providing the best facilities for university education for young men of promise, especially in science, and that it was this feeling which led him to come forward and supplement the efforts which were being made at University College for the provision of chemical laboratories of the best and most up-to-date character.

After the speeches, the company adjourned from the large Chemistry Theatre to the Hall of the Chemistry Laboratories, when the unveiling was performed by Lord Chelmsford. The tablet, which was designed by Prof. F. M. Simpson, is of white marble surrounded by a green marble border. It bears the inscription : "The Ralph Forster Organic Chemistry Laboratory, so named in grateful recognition of the generosity of Sir Ralph Forster, Bt. MCMXI."

\section{Cinema Film of the Total Eclipse of the Sun at Wallal, Australia, September 2I, I922.}

THERE have been in the past several proposals to take a cinema film of a total eclipse of the sun, but the first real outcome of these proposals is the film now being shown at the Royal Albert Hall. The pictures illustrate the experiences and the work of the astronomers of the expedition, under Prof. W. W. Campbell, to Wallal, on the north-west coast of Australia, from the time they left Perth until after the eclipse. The journey to Broome was made on the S.S. Charon, and afterwards on the lugger Gwendoline, towed by a lighthouse tender, to Ninety Mile Beach. On account of the great rise and fall of the tides, the ship had to anchor five miles out, and the astronomers with all their baggage had to be landed in boats through the surf. The equipment was then transported on donkey waggons to the site selected for the camp, and in this work the aboriginal inhabitants of the country, both men and women, gave considerable assistance. The large amount of dust, which rose in clouds wherever there was any work being done, caused great inconvenience. Nevertheless a large camp was soon set up and the assembling of the instruments commenced. The process of erection of the tower telescope and of the equatorials and colostats, as well as the various rehearsals in changing plates and uncovering object-glasses, are well illustrated. The part of the film showing the solar corona is good, considering that it was taken with a cinema lens, but a better picture could easily be constructed from the negatives taken by the eclipse party.

The film will enable those who are interested in scientific work to appreciate the difficulties which eclipse observers often have to face. Large and cumbersome instruments have to be transported long distances and often erected in almost inaccessible places where little or no skilled labour can be obtained. The conditions at Wallal were probably more difficult than usual, but were bravely faced and overcome. A wireless apparatus was erected to keep the eclipse party in communication with the outside world, and a weekly aeroplane service was instituted. The film is well worth seeing by those interested in the work of scientific expeditions. It would have been too much to expect that a film of this kind, taken under such difficult conditions, would come up to the standard of the films produced by special actors in artificial conditions. However, the fact that the actual work of the astronomers is interspersed with pictures illustrating the life of the natives should make the film one of more general interest. With these additions the showing of the film takes a little over an hour. The attempt to produce a film showing the actual work of a scientific expedition is one which deserves every encouragement and we wish it every success.

\section{University and Educational Intelligence.}

Brrmingham.-Applications are invited for the James Watt research fellowship in the thermodynamics of internal combustion engines. Particulars of the fellowship, which is of the annual value of $220 l$., may be obtained from the Dean of the Faculty of Science of the University. The latest date for the receipt of applications is May 31 .

NO. 2794 , VOL. I I I ] 